\title{
Prostate cancer cell malignancy via modulation of HIF-1 $\alpha$ pathway with isoflurane and propofol alone and in combination
}

\author{
H Huang ${ }^{1,2,4}$, L L Benzonana ${ }^{1,4}, \mathrm{H}_{\text {Zhao }}{ }^{1,4}, \mathrm{H}$ R Watts ${ }^{1}$, N J S Perry ${ }^{1}, \mathrm{C}$ Bevan $^{3}$, R Brown ${ }^{3}$ and D Ma ${ }^{*, 1}$ \\ ${ }^{1}$ Section of Anaesthetics, Pain Medicine and Intensive Care, Division of Surgery, Department of Surgery and Cancer, Faculty of \\ Medicine, Imperial College London, Chelsea and Westminster Hospital, London, UK; ${ }^{2}$ Department of Anesthesiology, West China \\ Second Hospital, Sichuan University, Chengdu, China and ${ }^{3}$ Division of Cancer, Department of Surgery and Cancer, Faculty of \\ Medicine, Imperial College London, London, UK
}

Background: Surgery is considered to be the first line treatment for solid tumours. Recently, retrospective studies reported that general anaesthesia was associated with worse long-term cancer-free survival when compared with regional anaesthesia. This has important clinical implications; however, the mechanisms underlying those observations remain unclear. We aim to investigate the effect of anaesthetics isoflurane and propofol on prostate cancer malignancy.

Methods: Prostate cancer (PC3) cell line was exposed to commonly used anaesthetic isoflurane and propofol. Malignant potential was assessed through evaluation of expression level of hypoxia-inducible factor-1 1 (HIF-1 $\alpha$ ) and its downstream effectors, cell proliferation and migration as well as development of chemoresistance.

Results: We demonstrated that isoflurane, at a clinically relevant concentration induced upregulation of HIF-1 $\alpha$ and its downstream effectors in PC3 cell line. Consequently, cancer cell characteristics associated with malignancy were enhanced, with an increase of proliferation and migration, as well as development of chemoresistance. Inhibition of HIF-1 $\alpha$ neosynthesis through upper pathway blocking by a PI-3K-Akt inhibitor or HIF-1 $\alpha$ siRNA abolished isoflurane-induced effects. In contrast, the intravenous anaesthetic propofol inhibited HIF-1 $\alpha$ activation induced by hypoxia or $\mathrm{CoCl}_{2}$. Propofol also prevented isoflurane-induced HIF-1 $\alpha$ activation, and partially reduced cancer cell malignant activities.

Conclusions: Our findings suggest that modulation of HIF-1 $\alpha$ activity by anaesthetics may affect cancer recurrence following surgery. If our data were to be extrapolated to the clinical setting, isoflurane but not propofol should be avoided for use in cancer surgery. Further work involving in vivo models and clinical trials is urgently needed to determine the optimal anaesthetic regimen for cancer patients.

Cancer is a leading cause of death worldwide and its incidence is set to increase from 12.7 million new cases in 2008 to an estimated 26 million by 2030 (Bray et al, 2012). As surgery remains the mainstay treatment option for most solid tumours, there is valid impetus to define the factors within the perioperative period that have the potential to affect the longer-term outcome of patients after surgery, particularly in terms of cancer recurrence. One such factor, subject to much speculation in recent years, is anaesthetics and/or anaesthetic technique.

Accumulating clinical evidence indicates that general anaesthesia combined with regional anaesthesia is associated with improved outcomes in patients undergoing surgery for a variety of cancers when compared with general anaesthesia alone (Exadaktylos et al, 2006; Biki et al, 2008b; Christopherson et al, 2008;

\footnotetext{
*Correspondence: Dr D Ma; E-mail: d.ma@imperial.ac.uk
}

${ }^{4}$ These authors contributed equally to this work.

Revised 23 May 2014; accepted 3 July 2014; published online 29 July 2014

(c) 2014 Cancer Research UK. All rights reserved 0007-0920/14 
Lin et al, 2011). A much-cited example is a retrospective study involving 225 patients with prostate cancer undergoing radical prostatectomy in which it was reported that general anaesthesia combined with epidural anaesthesia was associated with a 57\% lower recurrence rate (Biki et al, 2008a) when compared with general anaesthesia alone. It is argued that general anaesthesia using inhalational agents is immunosuppressive, whereas the use of regional anaesthesia helps attenuating surgical stress and the associated neuroendocrine responses, perhaps accounting for the observed association between use of regional anaesthesia and a higher disease-free survival rate (Biki et al, 2008b; Welden et al, 2009; Gottschalk et al, 2010; Lin et al, 2011; de Oliveira et al, 2011; Gottschalk et al, 2012). However, other mechanisms beyond the immunosuppressive effect of general anaesthetics may also play an important contributory role in this process.

One such mechanism involves the action of anaesthetics on a specific cell signalling pathway. Inhaled anaesthetics such as xenon have been shown to upregulate transcription factors, for example, hypoxia-inducible factor- $1 \alpha$ (HIF- $1 \alpha$ ), a phenomenon that appears to underpin the cytoprotective effects of these agents on organs experiencing hypoxic injury (Ma et al, 2009). Conversely, the intravenous anaesthetic, propofol, has been shown to have the opposite effect, suppressing HIF- $1 \alpha$ protein synthesis in an oxygen tension-dependent manner (Takabuchi et al, 2004b).

Hypoxia induces crucial biological responses in tumour growth (Liao \& Johnson, 2007). HIF- $1 \alpha$ has been identified as a key regulator of this process, which activates a spectrum of downstream genes to promote cell proliferation (Terraneo et al, 2010; Wang et al, 2011), angiogenesis (Ban et al, 2010; EisingerMathason and Simon, 2010) and metastasis (Burrows et al, 2011). Cancer cells take advantage of the ensuing phenotypic responses, not only in promoting cell survival in the harsh tumour environment but also in gaining competitive advantage over neighbouring, healthy cells. High levels of HIF- $1 \alpha$ within a tumour have been associated with poorer patient prognosis and it has been considered as a potential therapeutic target in cancer (Semenza, 2003b). It is therefore rational to predict that the further upregulation of HIF- $1 \alpha$ by an anaesthetic would compound or even enhance its effect of promoting malignant behaviour in cancer cells, whereas the use of an agent such as propofol which has been shown to inhibit HIF- $1 \alpha$ activity might prove helpful in bringing about the opposite effect.

Using a well-established prostate cancer (PC3) cell line, the aim of this study was to investigate the impact of anaesthetic-induced HIF- $1 \alpha$ activation in cancer cells, comparing the inhalational anaesthetic isoflurane with the intravenous anaesthetic, propofol, alone and in combination.

\section{MATERIALS AND METHODS}

Cell culture. Human authenticated prostate adenocarcinoma PC3 cancer cell line, derived from an advanced androgen-independent bone-metastasised prostate cancer, were cultured in monolayer in $75-\mathrm{cm}^{2}$ tissue culture flasks (VWR, Leistershire, UK). They were maintained at $37 \mathrm{C}$ in humidified air balanced with $5 \% \mathrm{CO}_{2}$ in RPMI 1640 medium (GIBCO, Invitrogen, Paisley, UK) supplemented with $10 \%$ heat-inactivated fetal calf serum (Thermo Scientific, Epsom, UK), $2 \mathrm{~mm}$ L-glutamine and $100 \mathrm{U} \mathrm{ml}^{-1}$ penicillin-streptomycin (Invitrogen). Culture medium was replaced every $48 \mathrm{~h}$.

Isoflurane exposure. Before gas exposure, PC3 cells were cultured at $1 \times 10^{6}$ per $\mathrm{ml}$ density on $30-\mathrm{mm}^{2}$ Petri dishes (VWR, Leistershire, UK) and used $24 \mathrm{~h}$ later when they were $80 \%$ confluent. Cell media was replaced either with fresh RPMI 1640 medium supplemented with serum and then placed in 1.51 purpose-built airtight, temperature-controlled chambers equipped with inlet and outlet valves and an internal electric fan used to provide continuous delivery and mixture of gases. For cell cycle study, cell media was without serum as the cell cycle can be synchronized through serum deprivation (Gopinathan et al, 2014). The chamber was connected to calibrated flow meters and an inline vaporiser used to deliver the desired composition (Datex gas monitor, Helsinki, Finland) of isoflurane (0.5-2.0\%) (Abbott Laboratories, Maidenhead, UK) in $21 \%$ oxygen and $5 \% \mathrm{CO}_{2}$ balanced with nitrogen (BOC, Guildford, UK). The chamber was pre-flushed with the aforementioned gas mixture to ensure that a stable gas composition was achieved, and a closed system was established to prevent leakage. Gas treatment was given at the desired isoflurane concentration for $2 \mathrm{~h}$ at $37^{\circ} \mathrm{C}$. The cells were then removed and the serum-free medium was replaced with fullculture medium and the Petri dishes were returned to a standard incubator containing humidified air and $5 \% \mathrm{CO}_{2}$ at $37^{\circ} \mathrm{C}$ for further analysis. Cells used as the naïve control group were placed in an identical gas chamber containing $21 \%$ oxygen and $5 \% \mathrm{CO}_{2}$ balanced with nitrogen at $37^{\circ} \mathrm{C}$. Cells were analysed at different time points ranging from $0-24 \mathrm{~h}$ post gas exposure.

Propofol treatment. Two formulations of propofol were used, dissolved in either $10 \%$ intralipid (the formulation for clinical use, from Astra-Zeneca, London, UK) or in DMSO (Sigma-Aldrich, Dorset, UK). Before treatment, PC3 cells were cultured at the density of $1 \times 10^{6}$ per $\mathrm{ml}$ on a $30-\mathrm{mm}^{2}$ Petri dishes, as described above.

In the case of propofol in intralipid formation, propofol was diluted with PC3 medium to a stock concentration of $0.4 \mathrm{mg} \mathrm{ml}^{-1}$. On the day of the experiment, the stock solution of propofol was diluted with PC3 serum-free medium to the desired concentrations $\left(0.5-10 \mu \mathrm{g} \mathrm{ml}^{-1}\right)$. For the intralipid control, $20 \%$ intralipid was diluted in cell medium to recreate the amount of intralipid in the highest $10 \mu \mathrm{g} \mathrm{ml}^{-1}$ dose of propofol being used. In the case of propofol in DMSO, prior to incubating the cells, propofol was dissolved to clinically relevant concentrations $\left(1-4 \mu \mathrm{g} \mathrm{ml}^{-1}\right)$ with PC3 serum-free medium. The DMSO control corresponded to the amount of DMSO $(0.05 \%)$ in the $4 \mu \mathrm{g} \mathrm{ml}^{-1}$ dose of propofol. Propofol-supplemented medium was then added to the cell cultures for $2 \mathrm{~h}$. Cells were then washed with Dulbeccos phosphate-buffered saline (DPBS; GIBCO, Invitrogen) and replaced with normal PC3 cell culture medium. For exposure to both isoflurane and propofol, cells were treated with propofol $\left(0-10 \mu \mathrm{g} \mathrm{ml}^{-1}\right.$ in either lipid or DMSO)-supplemented media and then exposed to $2 \%$ isoflurane for $2 \mathrm{~h}$. Following exposure, propofol medium was replaced with full PC3 cell medium and cells were harvested $24 \mathrm{~h}$ following anaesthetic treatment.

Cobalt chloride-mediated HIF-1 $\alpha$ induction. A 1-mM stock solution of cobalt chloride $\left(\mathrm{CoCl}_{2}\right)$ was prepared by dissolving $\mathrm{CoCl}_{2}$ powder (Sigma-Aldrich, Dorset, UK) in $\mathrm{dH}_{2} \mathrm{O}$, this stock solution was then further diluted to a concentration of $100 \mu \mathrm{M}$ with serum-free propofol (0-4 $\mu \mathrm{g} \mathrm{ml}^{-1}$ in intralipid)-supplemented PC3 medium. Before treatment, PC3 cells were cultured at a density of $1 \times 10^{6}$ per $\mathrm{ml}$ on $30-\mathrm{mm}^{2}$ Petri dishes, as described above. Complete medium was then replaced with $\mathrm{CoCl}_{2}$ and propofol-supplemented medium for $6 \mathrm{~h}$. Cells were harvested immediately after exposure for western blotting.

Hypoxic HIF-1 $\alpha$ induction. Cells were placed in a gas chamber as described earlier and exposed to a mixture of $1 \%$ oxygen balanced in nitrogen, and $5 \% \mathrm{CO}_{2}$ for $18 \mathrm{~h}$ at $37^{\circ} \mathrm{C}$ in the presence $\left(1-4 \mu \mathrm{g} \mathrm{ml}^{-1}\right)$ or absence of propofol. The cells were then immediately harvested for western blotting.

siRNA-mediated HIF-1 $\alpha$ knockdown. PC3 cells were transfected with high-quality human-specific HIF- $1 \alpha$ siRNA (Qiagen, Sussex, UK): 
sense strand $5^{\prime}$-GAAGAACUAUGAACAUAAATT- ${ }^{\prime}$; antisense strand $5^{\prime}$-UUUAUGUUCAUAGUUCUUCCT- $3^{\prime}$ ). A scrambled non-sense siRNA (Qiagen) without specific gene-silencing activity was used as a negative control. Transfection was achieved using lipofectamine RNAi MAX (Invitrogen). PC3 cells were cultured at the density of $0.4 \times 10^{6}$ per $\mathrm{ml}$ and treated with siRNA targeting human HIF- $1 \alpha$ or scrambled siRNA dissolved in siRNA suspension buffer supplement with lipofectamine which was administered to PC3 cells in a dose of $20 \mathrm{~nm}$. Cells were incubated with siRNA for $6 \mathrm{~h}$ at $37^{\circ} \mathrm{C}$ in humidified air containing $5 \% \mathrm{CO}_{2}$, after which the cells were washed with DPBS, then serum-free medium was added followed by isoflurane gas exposure and/or propofol exposure and in conjuction with the chemotherapeutic agent Docetaxel (see below).

Treatment with a chemotherapeutic agent. A typical anti-mitotic chemotherapeutic agent for prostate cancer, Docetaxel (DTX), was used in conjuction with isoflurane and propofol treatments on PC3 cells. Twenty-four hours post isoflurane exposure or propofol treatment with or without siRNA pre-treatment, DTX (Tocris, Bristol, UK) of 1-mM stock solution was diluted to a concentration of $10-100 \mu \mathrm{M}$ with PC3 medium. Cell medium was then replaced with DTX-supplemented medium for $24 \mathrm{~h}$.

PI3K and MEK inhibition. PC3 cells were cultured at a density of $1 \times 10^{6}$ per $\mathrm{ml}$ in $30-\mathrm{mm}^{2}$ petri dishes and then treated with either a selective inhibitor of phosphatidylinositol 3 kinase (PI3K), LY294002 (Cell signaling, Hitchin, UK) or a selective inhibitor of mitogen-activated protein/extracellular-regulated kinase (MAPK/ ERK), U0126 (Cell signaling) for $16 \mathrm{~h}$ at $37^{\circ} \mathrm{C}$ in a humidified atmosphere containing $5 \% \mathrm{CO}_{2}$ prior to isoflurane and/or propofol exposure. Both chemicals were dissolved in sterile DMSO to create a stock concentration of $10 \mathrm{~mm}$. For the final solution, they were further diluted with serum-free culture medium to the final working concentration of $50 \mu \mathrm{M}$, with concentration of DMSO being $0.05 \%$. Cells were harvested for western blotting immediately after anaesthetic exposure.

Western blotting. Control or treated PC3 cells described above were washed with ice-cold PBS buffer and lysed on ice by physical disruption using a cell scraper in $20 \mathrm{~mm}$ Tris- $\mathrm{HCl}$ ( $\mathrm{pH} 7.5), 150 \mathrm{~mm}$ $\mathrm{NaCl}, 1 \mathrm{~mm} \mathrm{Na}{ }_{2}$ EDTA, 2 mM EGTA, 1\% Triton, $2.5 \mathrm{~mm} \mathrm{Na}_{4} \mathrm{P}_{2} \mathrm{O}_{7}$, $1 \mathrm{~mm}$ beta-glycerophosphate, $1 \mathrm{~mm} \mathrm{Na}_{3} \mathrm{VO}_{4}, 1 \mu \mathrm{g} \mathrm{ml}^{-1}$ leupeptin, $1 \mathrm{~mm}$ phenyl methane sulphonyl fluoride and $1 \mathrm{~mm}$ dithiothreitol cell lysis buffer (Cell Signalling). The samples were centrifuged at 13000 r.p.m. for $30 \mathrm{~min}$ at $4 \mathrm{C}$, and the supernatant was collected. Total protein concentration was quantified using the Bradford protein assay (Bio-Rad Laboratories, Hercules, CA, USA) and protein extracts were normalised for protein content to $40 \mu \mathrm{g}$ per sample. Protein extracts were added to sodium dodecyl sulphate (SDS) sample buffer (Invitrogen) at 1:3 ratio, heated for $10 \mathrm{~min}$ at $95^{\circ} \mathrm{C}$ and then loaded on a NuPAGE $4-12 \%$ Bis-Tris gel (Invitrogen) for electrophoresis. Following electrophoresis, they were transferred to a polyvinylidenedifluoride (PVDF) membrane and blocked overnight in 5\% non-fat powdered milk in $0.1 \%$ Tween 20/tris-buffered saline (TBST) at $4 \mathrm{C}$. The membranes were then probed with the following primary antibodies: mouse antiHIF- $1 \alpha$ (BD Biosciences, San Jose, CA, USA); rabbit anti-Bcl-2 (Abcam, Cambridge, UK); rabbit anti-HIF-1 $\beta$ (Cell Signaling); rabbit anti-phospho-Akt (Cell Signaling); mouse anti-phosphoERk (Cell Signaling), in 5\% non-fat dry milk in TBST overnight at $4{ }^{\circ} \mathrm{C}$, followed by HRP-conjugated anti-mouse or anti-rabbit secondary antibodies (Cell Signaling) for $1 \mathrm{~h}$. The loading control was the constitutively expressed protein $\alpha$-tubulin (Sigma-Aldrich, Dorset, UK). The blots were washed with TBST for 5 min three times followed by one wash with TBS and were visualised using the enhanced chemiluminescence (ECL) system (Santa Cruz, Dallas, TX, USA). The protein bands were captured with an image processor using the Syngene GeneSnap software (Syngene, Cambridge, UK) and the intensity of the bands corresponding to the protein expression level was measured using GeneTools software (Syngene, Cambridge, UK). Results were normalised to levels of the housekeeping protein $\alpha$-tubulin and expressed as ratio of the control for data analysis.

Immunocytochemistry. PC3 cells were fixed in 4\% paraformaldehyde for $10 \mathrm{~min}$, rinsed in PBS (Sigma-Aldrich) two times for 5 min, permeabilised with $0.1 \%$ Triton X-100 in PBS (PBS-T) for $10 \mathrm{~min}$ and washed twice for $5 \mathrm{~min}$. Blocking was carried out at room temperature for $1 \mathrm{~h}$ using 10\% normal goat serum (Vector Laboratories, Peterborough, UK).

Cells were incubated overnight at $4{ }^{\circ} \mathrm{C}$ in blocking solution containing one of the following antibodies: rabbit anti-HIF- $1 \alpha$ (Novus Biologicals, Littleton, CO, USA), rabbit anti-VEGF (Abcam), mouse anti-Ki-67 (Dako, Cambridge, UK), mouse anticytochrome $c$ (BD Biosciences, San Jose, CA, USA), mouse anticyclin D (Abcam), mouse anti-cyclin E (Abcam). Following three PBS rinses, cells were incubated for $2 \mathrm{~h}$ in PBS-T containing one of the following secondary antibodies: Rhodamine-conjugated donkey anti-rabbit IgG (Millipore, Oxford, UK), Fluorescein isothiocyanate (FITC)-conjugated donkey anti-rabbit IgG (Millipore) or FITC-conjugated anti-rabbit (Millipore), followed by final PBS rinses and coverslipping with Vectorshield fluorescence medium containing 4',6-diamidino-2-phenylindole (DAPI) (Vector Laboratories). In the case of double labeling, the following combinations of antibodies were used for this study: HIF- $1 \alpha /$ VEGF, HIF- $1 \alpha /$ Ki-67, HIF- $1 \alpha /$ cyclin D and HIF- $1 \alpha /$ cyclin E, PC3 cells were incubated with the first primary antibody overnight, followed by the first secondary antibody, and then the second primary antibody and the second secondary antibody. Images of 10 high-power fields (HPFs) at $\times 20$ magnification were obtained using an AxioCam digital camera (Zeiss, Welwyn Garden City, $\mathrm{UK}$ ) mounted on an Olympus BX60 microscope (Olympus, Middlesex, UK) with Zeiss KS-300 software (Zeiss). Images were captured under identical exposure settings and final assessments were conducted under blinded conditions. In the case of HIF- $1 \alpha$, HIF-1 $\alpha /$ VEGF, HIF- $1 \alpha /$ ki67 and cytochrome- $c$ staining, images were used for qualitative analysis. For ki67 staining, eight representative fields were randomly selected and the mean pixel intensities for ki67-positive cells were measured through ImageJ 1.35 software (NIH, Bethesda, MD, USA). Ki67-positive cells were then presented as a percentage of the total number of DAPIpositive cells.

Cell viability test (MTT Assay). The viability of cells was assessed by using a colorimetric 3-(4, 5-dimethyl-2-thiazolyl)-2, 5-diphenyl2H-tetrazolium bromide (MTT); (Merck KGaA, Darmstadt, Germany) assay. MTT was diluted with minimum essential medium + Earle's - L-glutamine $\times 1$ (MEM) (GIBCO, Invitrogen) to a concentration of $0.5 \mathrm{mg} \mathrm{ml}^{-1}$. Cells were then incubated with $0.5 \mathrm{mg} \mathrm{ml}^{-1}$ of MTT for $2 \mathrm{~h}$ at $37^{\circ} \mathrm{C}$ in a humidified atmosphere containing $5 \% \mathrm{CO}_{2}$. The solution was then carefully aspirated out and $1 \mathrm{ml}$ of DMSO, (Fisher Scientific, Leicestershire, UK) was added to dissolve the purple-coloured formazan particles and form a homogeneous purple colour. The samples from duplicate wells were transferred to a 96-well plate, and the absorbance of dissolved formazan crystals was spectrophotometrically assessed at a wavelength of $595 \mathrm{~nm}$, using an Mrx microplate reader (Dynex Technologies, Chantilly, VA, USA) and presented in arbitrary units. Viability was defined as the ratio of the optical density of formazan in the treated group against that in the control.

Scratch assay. The scratch assay (wound-healing assay) was performed for assessing tumour cell migration, as previously described (Liang et al, 2007). After cultured cells became confluent in 24-well plates, one artificial gap created by a sterile plastic 
micropipette tip $(1000 \mu \mathrm{l})$ to generate a uniform gap that was devoid of adherent cells. Gap closure was monitored with digital camera images taken in a phase-contrast microscope equipped with a digital camera (Olympus CK30, Tokyo, Japan). Images were analysed using ImageJ. The same scratch was analysed before and $24 \mathrm{~h}$ after treatment using ImageJ 1.35 software. Wound healing was quantified as the mean percentage of the remaining cell-free area compared with the area of the initial wound (Hu \& Verkman, 2006).

Enzyme-linked immunosorbent assay (ELISA). Cultured cell medium with or without treatments was harvested for MMP-2 and MMP-9 measurements determined with ELISA kits (R\&D Systems, Oxon, UK) following the manufacturer's instructions.

Statistical analysis. All numerical data were expressed as mean \pm s.d. Comparison between different treatments was analysed by one-way ANOVA followed by post hoc StudentNewman-Keuls test using GraphPad Prism (GraphPad Software, La Jolla, CA, USA). A $P$-value $<0.05$ was considered to be statistically significant.

\section{RESULTS}

Isoflurane induced persistent HIF-1 $\alpha$ expression and translocation at clinically relevant concentrations. In order to distinguish the effects of isoflurane exposure on HIF- $1 \alpha$ protein levels, PC3 cells were exposed to $0.5-2 \%$ isoflurane for $2 \mathrm{~h}$, and cells were harvested at $0,2,4,8$ and $24 \mathrm{~h}$ after gas exposure and examined using western blotting and immunocytochemistry. Isoflurane exposure induced a marked increase in HIF- $1 \alpha$ protein level in a time-dependent (Figure 1A) and a dose-dependent manner (Figure 1B). Specifically, exposure to $2 \%$ isoflurane triggered significant upregulation of HIF- $1 \alpha$ protein levels, which was observed from $4 \mathrm{~h}(3.33 \pm 0.59$ vs 1.00 of NC, $P<0.001$; Figure $1 \mathrm{~A})$ post gas exposure, maintained at $8 \mathrm{~h}(3.19 \pm 0.62 v s 1.00$ of $\mathrm{NC}$, $P<0.001$; Figure 1A) and was maximally increased $24 \mathrm{~h}$ post exposure (3.74 \pm 0.81 vs 1.00 of $\mathrm{NC}, P<0.001$; Figure $1 \mathrm{~A})$. Furthermore, isoflurane-induced activation of HIF- $1 \alpha$ expression was dose-dependent with significant increases after exposure with $1.5 \%$ isoflurane $(2.11 \pm 0.58$ vs 1.00 of $\mathrm{NC}, P=0.041$; Figure $1 \mathrm{~B})$ and $2 \%$ isoflurane $(3.20 \pm 0.92$ vs 1.00 of NC, $P<0.001$, Figure $1 \mathrm{~B})$. Moreover, it was observed that $24 \mathrm{~h}$ following isoflurane exposure there was a distinct translocation of HIF- $1 \alpha$ from the cytoplasm into the nucleus (compared with the naïve control) where it initiates downstream gene expression as a transcriptional regulator (Figure 1C). It is important to note that protein levels of HIF-1 $\beta$ remained unchanged after isoflurane exposure both in the time course $(P=0.9672$, Figure 1D) and the dose-response experiments $(P=0.6425$, Figure 1E).

Propofol inhibited activation of HIF- $1 \alpha$ induced by various stimulants. To test the effect of propofol on HIF- $1 \alpha$ expression, co-intervention experiments were performed with clinically relevant concentrations of propofol $\left(\leqslant 4 \mu \mathrm{g} \mathrm{ml}^{-1}\right)$ and HIF- $1 \alpha$ inducers: hypoxia, $\mathrm{CoCl}_{2}$ or isoflurane. Exposure times varied depending on the experiment performed. Cells were harvested either immediately after the co-intervention experiments (propofol and hypoxia or $\mathrm{CoCl}_{2}$ ), or at different time points for propofol alone $(0-24 \mathrm{~h})$, or at $24 \mathrm{~h}$ post-anaesthetic exposure for propofol and isoflurane. In order to exclude any effects of the propofol vehicle, DMSO and intralipid controls were used in these experiments as well as the naïve control. Exposure to hypoxia significantly increased HIF- $1 \alpha$ protein levels when compared with the naïve control ( $3.14 \pm 0.50 v s 1.00$ of naive, $P<0.01$; Figure $2 \mathrm{~A}$ ); an effect that was abrogated following co-exposure to hypoxia and propofol in a dose-dependent manner $(1.38 \pm 0.64$-fold of naïve for propofol at $2 \mu \mathrm{g} \mathrm{ml}^{-1}$ and $1.16 \pm 0.26$-fold of naïve for propofol at $4 \mu \mathrm{g} \mathrm{ml}^{-1}$ vs $3.14 \pm 0.50$-fold of naïve for isoflurane alone, $P<0.01$; Figure 2A). Similar results were observed for cells treated with both $\mathrm{CoCl}_{2}$ and propofol. $\mathrm{CoCl}_{2}$ was shown to induce HIF- $1 \alpha$ activation $(3.33 \pm 0.41 v s 1.00$ of naive, $P<0.01$, Figure 2B) and propofol negated this effect $(1.85 \pm 0.30$-fold of naïve for propofol at $1 \mu \mathrm{g} \mathrm{ml}^{-1}, 1.15 \pm 0.30$-fold of naïve for propofol at $2 \mu \mathrm{g} \mathrm{ml}^{-1}$ and $0.87 \pm 0.34$-fold of naïve for propofol at $4 \mu \mathrm{g} \mathrm{ml}^{-1} v s 3.33 \pm 0.41$-fold

\section{A}

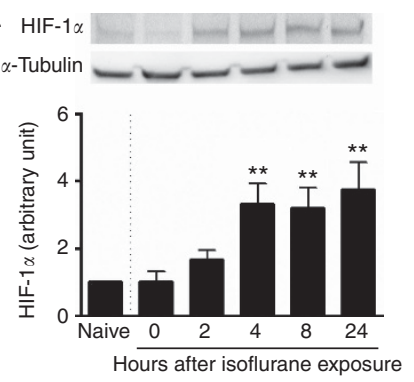

D

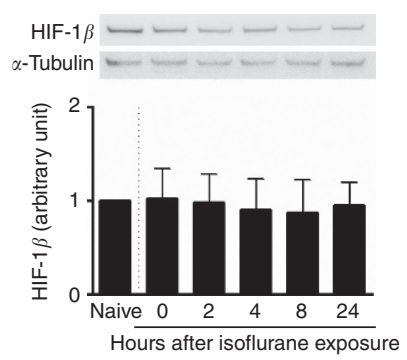

B

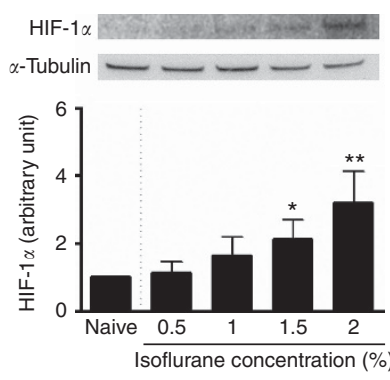

E

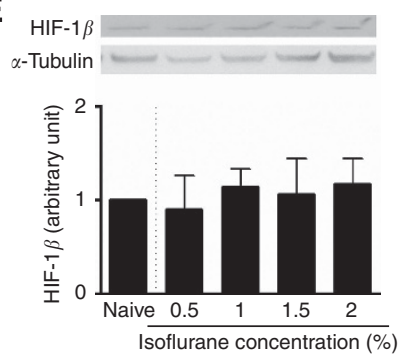

C
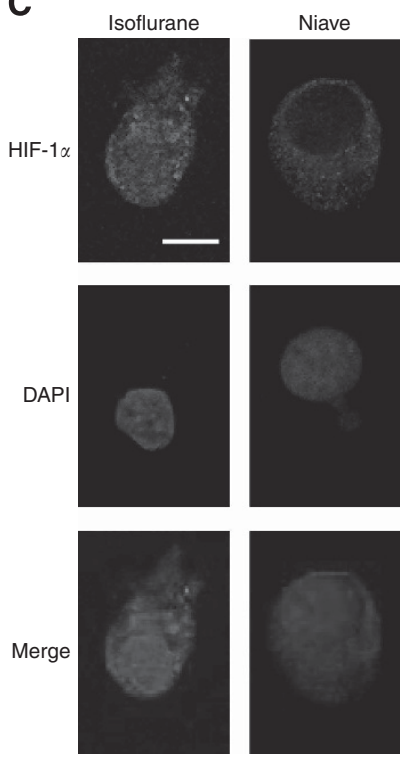

Figure 1. Effect of isoflurane exposure on expression and translocation of HIF-1 $\alpha$ in cultured human prostate cancer cells (PC3 cells). Cultured cells were exposed to $0.5-2 \%$ for $2 \mathrm{~h}$ and were harvested immediately or $2-24 \mathrm{~h}$ after exposure for western blotting. (A, B) A time- and concentration-dependent increase in HIF-1 $\alpha$ expression after isoflurane exposure; (C) immunostaining further revealed isoflurane exposure promoted the translocation of HIF-1 $\alpha$ from cytoplasm to nucleus where its downstream effects are initiated; (D, E) HIF-1 $\beta$ expression was unchanged after exposure to isoflurane. Results are expressed as mean \pm s.d.; ${ }^{*} P 0.05$; ${ }^{\star \star} P<0.001$ vs naïve control. Bar $=25 \mu$ m. 
A

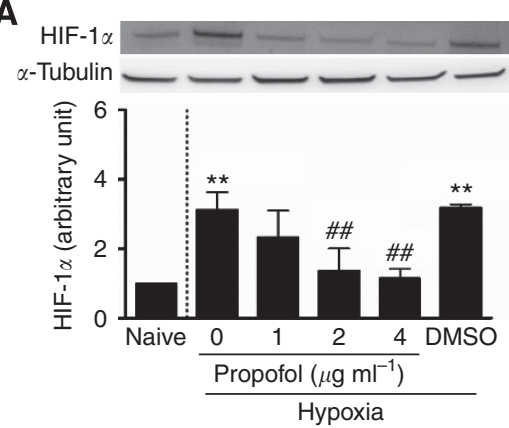

C

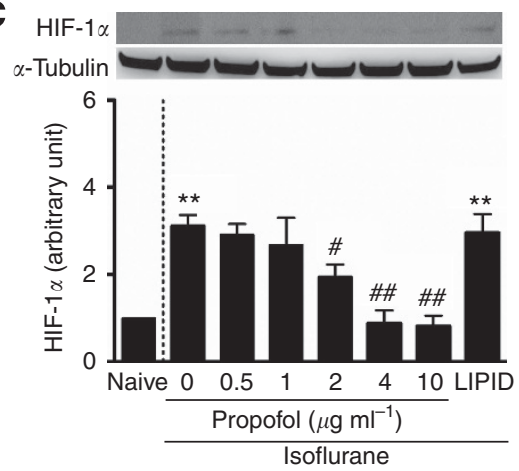

B

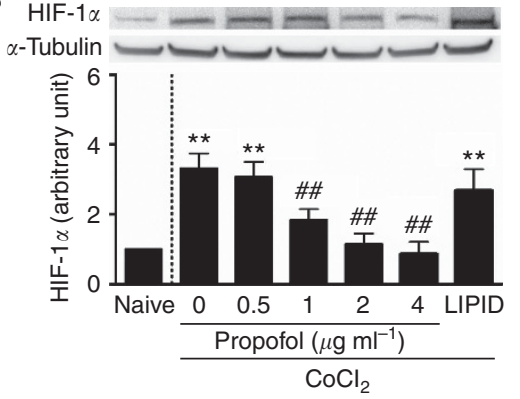

D

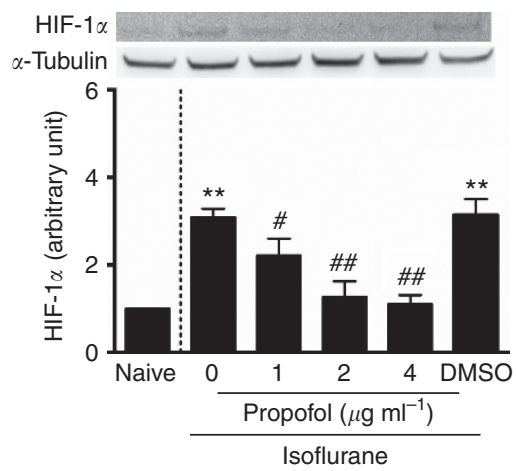

Figure 2. Propofol abolished increased HIF-1 $\alpha$ expression induced by various treatments in human prostate cancer cells. (A) Propofol abolished increased HIF-1 $\alpha$ production triggered by hypoxia (less than $1 \%$ oxygen for $18 \mathrm{~h}$ ); (B) propofol antagonised $\mathrm{CoCl}_{2}$-induced upregulation of $\mathrm{HIF}-1 \alpha$ $\left(\mathrm{CoCl}_{2}\right.$ at $100 \mu \mathrm{M}$ for $\left.6 \mathrm{~h}\right)$; propofol in intralipid (C) or DMSO (D) at clinically relevant concentrations $\left(2-4 \mu \mathrm{g} \mathrm{ml}^{-1}\right)$ effectively prevented isofluraneinduced activated expression of HIF- $1 \alpha$. Results are mean \pm s.d. $(n=4)$; ${ }^{\star} P<0.05 ;{ }^{\star \star} P<0.01$ vs naïve control. ${ }^{\#} P<0.05$; ${ }^{\# \#} P<0.01$ vs isoflurane or $\mathrm{CoCl}_{2}$ alone.

of naïve for isoflurane alone, $P<0.01$; Figure 2B). Most importantly, propofol abolished $2 \%$ isoflurane-induced HIF- $1 \alpha$ expression in a dose-dependent manner both when dissolved in lipid (1.95 \pm 0.28 -fold of naïve for propofol at $2 \mu \mathrm{g} \mathrm{ml}^{-1} P=0.04$, $0.89 \pm 0.59$-fold of naïve for propofol at $4 \mu \mathrm{g} \mathrm{ml}^{-1}$ and $0.82 \pm 0.48$ fold of naïve for propofol at $10 \mu \mathrm{g} \mathrm{ml}^{-1} v s 3.12 \pm 0.24$-fold of naïve for isoflurane alone, $P<0.01$; Figure $2 \mathrm{C}$ ) and when dissolved in DMSO $\left(2.25 \pm 0.38\right.$-fold of naïve for propofol at $1 \mu \mathrm{g} \mathrm{ml}^{-1}$ $P=0.048,1.27 \pm 0.35$-fold of naïve for propofol at $2 \mu \mathrm{g} \mathrm{ml}^{-1}$ and $1.11 \pm 0.21$-fold of naïve for propofol at $4 \mu \mathrm{g} \mathrm{ml}^{-1} v s$ $3.01 \pm 0.20$-fold of naïve for isoflurane alone, $P<0.01$; Figure $2 \mathrm{D}$ ).

Propofol and HIF-1 $\alpha$ siRNA inhibited isoflurane-induced VEGF upregulation and cell proliferation. We next investigated whether isoflurane increased VEGF levels and cell proliferation in PC3 cells and, furthermore, whether HIF- $1 \alpha$ inhibition through siRNA treatment and propofol treatment abrogated these effects. PC3 cells (with or without siRNA pre-treatment) were either exposed to $2 \%$ isoflurane alone for $2 \mathrm{~h}$ or in combination with $4 \mu \mathrm{g} \mathrm{ml}^{-1}$ of propofol for $2 \mathrm{~h}$. Cells were collected $24 \mathrm{~h}$ postanaesthetic exposure and used to determine HIF-1- $\alpha$ /VEGF and HIF-1- $\alpha /$ Ki67 levels through immunocytochemistry and cell proliferation rates with an MTT assay. Propofol at $4 \mu \mathrm{g} \mathrm{ml}^{-1}$ effectively blocked isoflurane-induced HIF- $1 \alpha$ expression and the associated expression of VEGF (Figure 3A and C) and Ki67 (Figure $3 \mathrm{~B}$ and $\mathrm{D}$ ), which are well-established markers for angiogenensis and active cellular proliferation, respectively. A similar inhibitory effect was also observed with HIF- $1 \alpha$-specific siRNA, which selectively blocked isoflurane-induced HIF- $1 \alpha$ overexpression (HIF- $1 \alpha$ level decreased from $2.47 \pm 0.42$ of isoflurane exposure $v s 1$ of $\mathrm{NC}$ to $0.74 \pm 0.11$ of isoflurane plus siRNA exposure $v s 1$ of NC, $P<0.001$; Supplementary Figure 1). Both VEGF (Figure 3A) and Ki67 levels (Figure 3B) were reduced as a result of HIF- $1 \alpha$ inhibition.
Isoflurane promoted cell cycle progression and cell proliferation, which was inhibited by propfol and HIF-1 $\alpha$ siRNA. We next assessed the cell cycle progression and cell proliferation after exposure to isoflurane. Enhanced cyclin D and cyclin E expression in PC3 cells was found after being exposed to isoflurane, and co-localization of HIF-1 $\alpha /$ cyclin D or HIF-1 $\alpha /$ cyclin E was noted (Figure 4A-D); the treatments with either propfol or HIF- $1 \alpha$ siRNA abolished these effects (Figure 4A-D) when compared with that treated with isoflorane. Cell viability was decreased from $1.41 \pm 0.12$ (relative to control) with isoflurane exposure to $1.10 \pm 0.20$ with isoflurane plus propofol exposure $(P=0.012)$ (Figure $4 \mathrm{E})$.

Isoflurane induced resistance to the chemotherapeutic agent docetaxel in PC3 cells, which could be reversed by propofol and HIF-1 $\alpha$-specific siRNA. The next step was to determine whether isoflurane and propofol had any effects on the efficacy of antimitotic chemotherapy drug commonly used in prostate cancer, DTX. To determine whether the efficacy of DTX was altered with changing HIF- $1 \alpha$ expression, PC3 cells were first exposed for $2 \mathrm{~h}$ to isoflurane, isoflurane plus propofol, or isoflurane in siRNA pretreated cells followed by treatment with DTX for $24 \mathrm{~h}$. Cells were harvested immediately after DTX treatment for immunocytochemistry and western blotting. It was observed that DTX was less effective in inhibiting active mitosis in isoflurane-exposed PC3 cells, evident by the $58.53 \pm 7.32 \%$ of actively dividing cells (Ki67 positive) when compared with the DTX treatment alone (25.61 $\pm 6.71 \%, P<0.001)$, or to the cells that were treated with propofol plus isoflurane $(17.96 \pm 11.56 \%, P<0.001)$ (Figure $5 \mathrm{~A}$ and $\mathrm{B}$ ) and to the cells that were treated with isoflurane plus siRNA $(27.52 \pm 8.88 \%, P<0.001$; Figure $5 \mathrm{~A})$. This was further supported by an MTT assay, which showed that isoflurane-pre-treated PC3 cells had a higher proliferation rate after DTX challenge, when compared with non-pre-treated PC3 cells $(0.36 \pm 0.03$-fold of naïve vs $0.13 \pm 0.05$-fold of naive, $P=0.006$; Figure $5 \mathrm{~B})$. With addition of propofol to isoflurane for the pre-treatment, the proliferation rate 

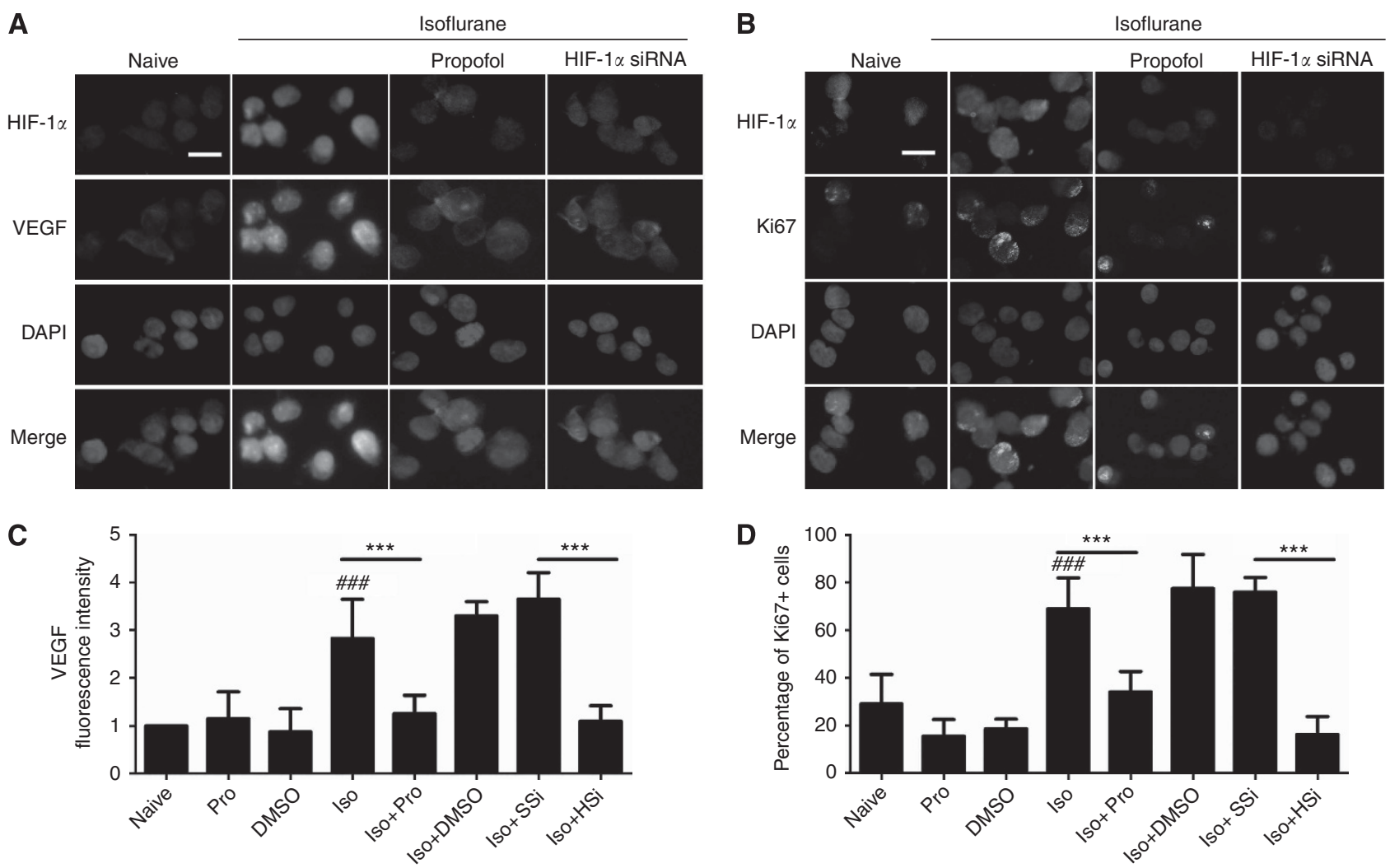

Figure 3. Isoflurane exposure increases human prostate cancer cell growth-promoting signalling and proliferation markers. Exposure to isoflurane induced activation of markers for angiogenesis (VEGF, (A)) and proliferation (Ki67, (B)), while propofol at $4 \mu \mathrm{g} \mathrm{ml}^{-1}$ or HIF-1 $\alpha$-specific siRNA $(20 \mathrm{~nm})$ abolished these changes. Fluorescent intensity of VEGF $(\mathbf{C})$ and percentage of $\mathrm{Ki}-67^{+}(\mathrm{D})$ cells were shown. ${ }^{\star} P<0.01$ vs naïve control; ${ }^{\star \star} P=0.001$ vs naïve control; ${ }^{\# \#} P<0.001$ naive control vs isoflurane alone. Abbreviations: $\mathrm{HSi}=\mathrm{HIF}-1 \alpha$ siRNA; Iso $=$ isoflurane; Pro $=$ propofol; $\mathrm{SSi}=$ scrambled siRNA. Bar $=50 \mu \mathrm{m}$.

was decreased $(0.18 \pm 0.04$-fold of naïve $v s \quad 0.36 \pm 0.03$-fold of naïve, $P=0.047)$. Furthermore, cytochrome $c$, a marker for cellular injury, was lower in the isoflurane and DTX co-treated cells when compared with DTX alone, isoflurane-propofol-DTX co-treated and isoflurane, siRNA and DTX groups (Figure 5C). This was coupled with overexpression of the anti-apoptotic Bcl-2 protein in cells with $2 \%$ isoflurane exposure and DTX treatment compared with cells with DTX treatment alone $(2.54 \pm 0.69$-fold of naïve $v s$ $0.45 \pm 0.23$-fold of naive, $P<0.001$; Figure $5 \mathrm{D}$, left panel and $2.49 \pm 0.50$-fold of naïve $v s 0.44 \pm 0.19$-fold of naive, $P<0.001$; Figure $5 \mathrm{D}$, right panel). The overexpression of $\mathrm{Bcl}-2$ was prevented with SiRNA pre-treatment $(2.54 \pm 0.69$-fold of naïve $v s 0.25 \pm 0.17$ fold of naive, $P<0.001$; Figure $5 \mathrm{D}$, left panel) and propofol pretreatment $(2.49 \pm 0.50$-fold of naïve $v s 0.33 \pm 0.12$-fold of naive, $P<0.001$; Figure 5D, right panel).

Phosphorylation of Akt, but not ERK, played an important role in the alteration of HIF-1 $\alpha$ expression induced by isoflurane or propofol. Collectively, these experiments established that isoflurane promotes cancer cell growth and survival in the face of various challenges via activation of HIF- $1 \alpha$ and upregulation of antiapoptotic protein BcL-2. Next, we determined the molecular basis underlying isoflurane-induced upregulation of HIF- $1 \alpha$. We investigated whether the PI3K/Akt/mTOR pathway and MAPK/ERK pathways were involved in the isoflurane-induced upregulation and propofol-induced downregulation of HIF-1 $\alpha$. PC3 cells were treated with either a PI3K inhibitor (LY294002) or an MAPK/ERK (MEK) 1/2 inhibitor (U0126) overnight, then were exposed to either isoflurane or isoflurane and propofol for $2 \mathrm{~h}$. Twenty-four hours later, the cells were harvested for western blotting and protein levels of HIF-1 $\alpha$, phosphorylated Akt (p-Akt) and phosphorylated ERK (p-ERK) were investigated. Phosphorylation of the kinase Akt, but not ERK 1/2, appear to play the dominant role in isoflurane-induced HIF- $1 \alpha$ overexpression. LY294002 blocked HIF- $1 \alpha$ overexpression showing a significant decrease in the inhibitor plus isoflurane group when compared with the isoflurane group alone ( $1.14 \pm 0.38$-fold of naïve $v s 4.16 \pm 1.02$-fold of naive, $P<0.001$ Figure $6 \mathrm{~A}$ ), but no significant changes when compared with the group that had also received propofol $(1.14 \pm 0.38$-fold of naïve $v s 1.29 \pm 0.61$-fold of naive, $P=1$; Figure 6A). By contrast, the MEK $1 / 2$ inhibitor, U0126, had no significant effect on HIF- $1 \alpha$ expression with the inhibitor plus isoflurane group showing no significant difference to the isoflurane group alone ( $3.13 \pm 0.67$-fold of naïve $v s 4.16 \pm 1.02$-fold of naive, $P=0.443$; Figure $6 \mathrm{~A}$ ), but did display a significantly higher amount of HIF- $1 \alpha$ protein relative to the group that received isoflurane plus propofol $(3.13 \pm 0.67$-fold of naïve $v s 1.29 \pm 0.61$ fold of naïve, $p=0.035$; Figure $6 \mathrm{~A}$ ). It was further shown that isoflurane and propofol had opposite effects on the phosphorylation of Akt kinase with isoflurane showing significantly higher amounts of $\mathrm{p}$-Akt when compared to the naive control (2.98 \pm 0.57 -fold of naïve $P<0.001$; Figure $6 \mathrm{~B})$, an effect abolished by pre-treatment with LY294002 $(2.98 \pm 0.57$-fold of naïve $v s$ $1.29 \pm 0.37, \quad P=0.002$; Figure $6 \mathrm{~B})$ and co-intervention with propofol (2.98 \pm 0.57 -fold of naïve $v s 1.68 \pm 0.63, \quad P=0.02$; Figure $6 \mathrm{~B})$. In terms of the phosphorylation of ERK, isoflurane alone showed an increasing trend compared to the naïve control but no significant change ( $1.71 \pm 0.52$-fold of naïve, $P=0.081$; Figure 6C). However, there was a significant decrease in the propofol $(0.95 \pm 0.26$-fold of naïve $v s 1.71 \pm 0.52, \quad P=0.048$; Figure 6C) and inhibitor groups $(0.79 \pm 0.27$-fold of naïve $v s$ $1.71 \pm 0.52, P=0.013$; Figure $6 \mathrm{C}$ ) when compared to isoflurane 
A

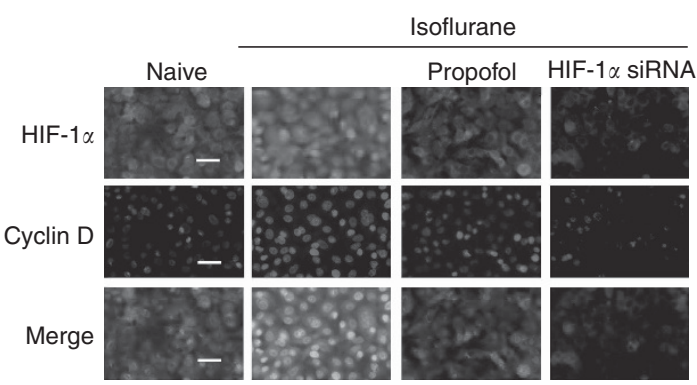

B

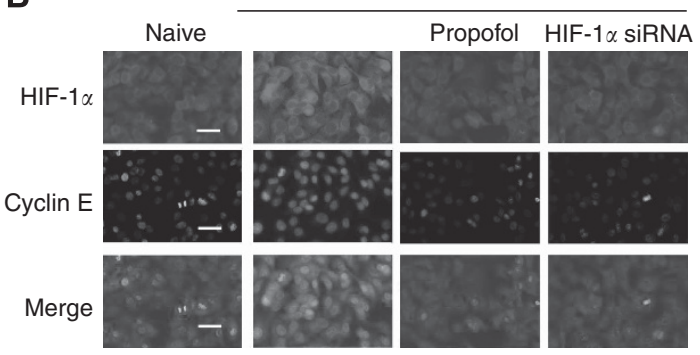

C
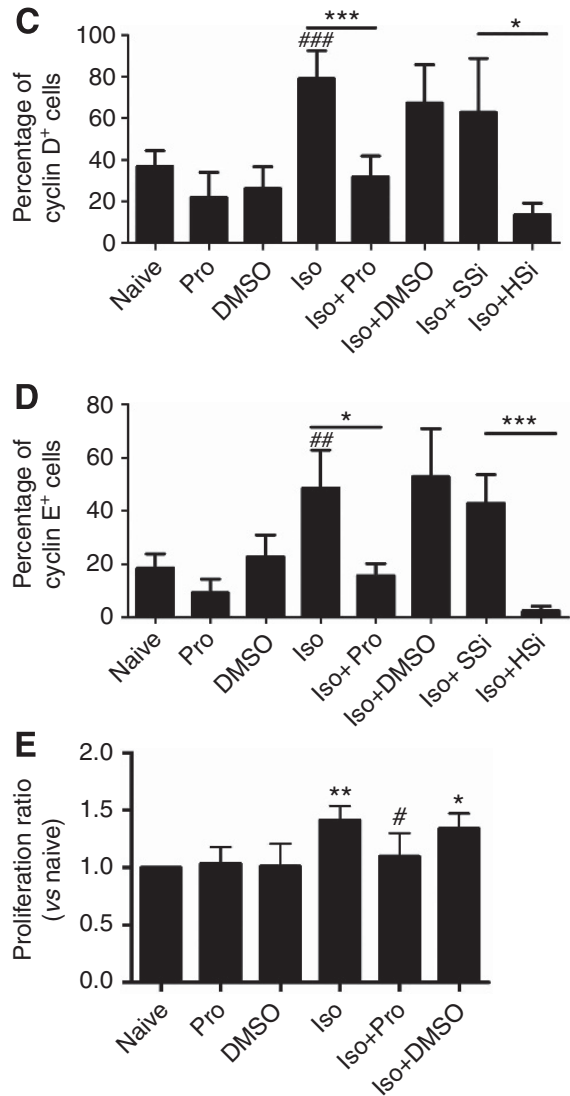

Figure 4. Isoflurane exposure enhanced human prostate cancer cell cycle progression and cell proliferation. (A and B) Dual labelling of cyclin D (green) or cyclin E (green) with HIF-1 (red). Exposure to isoflurane induced activation of markers for cell cycle (cyclin D, (A) and cyclin E, (B)), while propofol at $4 \mu \mathrm{g} \mathrm{ml}^{-1}$ or HIF-1 $\alpha$-specific siRNA (20nM) abolished these changes. Percentage of cyclin $\mathrm{D}^{+}$(C) and cyclin $\mathrm{E}^{+}$cells (D) after treatment. (E) MTT assay $(n=6)$ further indicated that propofol at $4 \mu \mathrm{g} \mathrm{ml}^{-1}$ effectively blocked isoflurane-induced cell proliferation. Results are mean $\pm \mathrm{s}$.d. $(n=6)$; ${ }^{\star} P<0.01$ vs naïve control; ${ }^{* \star} P=0.001$ vs naïve control; ${ }^{\# \#} P<0.001$ navie control vs isoflurane alone. Abbreviations: $H S i=H I F-1 \alpha$ siRNA; Iso = isoflurane; Pro = propofol; $\mathrm{SSi}=$ scrambled siRNA. $\mathrm{Bar}=50 \mu \mathrm{m}$. The full colour version of this figure is available at British Journal of Cancer online.

alone. In order to distinguish the potential different effects of isoflurane and propofol exposure on phosphorylation of Akt, PC3 cells were exposed to $2 \%$ isoflurane or $4 \mu \mathrm{g} \mathrm{ml}^{-1}$ propofol alone for $2 \mathrm{~h}$. Then protein samples were harvested at $0,2,4,8$ and $24 \mathrm{~h}$ after anaesthetics exposure. Isoflurane exposure induced a marked increase in p-Akt in a time-dependent manner (Figure 6D). Conversely, propofol exposure induced a marked decrease in p-Akt for initial $2 \mathrm{~h}$ after exposure and then return to a normal level which is likely due to positive feedback mechanism (Figure 6E). From these findings, it can be speculated that propofol prevented isoflurane-induced HIF- $1 \alpha$ overexpression by antagonising phosphorylation of Akt, although this inhibition could also partly be due to the decrease in the phosphorylation observed in ERK.

Isoflurane enhanced PC3 cell migration and invasion which was reversed by propofol and HIF-1 $\alpha$-specific siRNA. Enhanced MMP-2 and MMP-9 production was found in the cell medium treated with isoflurane, but not with the other treatments including propofol exposure (Figure 7A and B). Consistent with these results, data obtained from the scratch assay showed that isoflurane treatment significantly accelerated gap closure compared with controls at $24 \mathrm{~h}$ after a scratch was made (Figure $7 \mathrm{C}$ and D). Either propofol or HIF- $1 \alpha$ siRNA suppressed these effects (Figure $7 \mathrm{C}$ and D).

\section{DISCUSSION}

In this study using cultured prostate cancer PC3 cells, we show that isoflurane, one of the most commonly used inhaled anaesthetics, activates HIF- $1 \alpha$ expression in an oxygen-independent manner which, in turn, enhances cancer cell proliferation and migration together with the reinforcement of chemotherapy resistance. In contrast, propofol, the most commonly used intravenous anaesthetic, had no effect on HIF- $1 \alpha$ expression in PC3 cells when used alone but it was capable of inhibiting chemical- or isofluraneinduced HIF- $1 \alpha$ overexpression.

HIF- $1 \alpha$ activation in cancer has been heavily implicated in disease progression. Elevated levels have been found in a variety of human cancers (Talks et al, 2000) and correlated with tumour growth, vascularisation, metastasis and hence poor prognosis (Semenza, 2012). As transcription factors directly govern the expression of hundreds of genes, HIFs orchestrate crucial steps in tumorigenesis including angiogenesis, metabolic reprogramming, proliferation, metastasis and invasion, thus proving an attractive target for cancer therapy (Semenza, 2010; Semenza, 2012). Intuitively, it follows that exposure to a stimulus that further boosts HIF- $1 \alpha$ levels and its associated repertoire of downstream activities in cancer cells would add fuel to the flames.

Isoflurane exposure induced a more than three-fold rise in HIF- $1 \alpha$ level and did so in a dose-dependent manner, this was sustained and continued as long as $24 \mathrm{~h}$ afterward. In contrast, hypoxia induced only a transient overexpression of HIF- $1 \alpha$ in renal cancer or normal cells in previous reports (Ma et al, 2009). As demonstrated clearly in this study, HIF- $1 \alpha$ was seen to translocate from cytoplasm to nucleus where it assumes its role as a transcription factor. There was also a concomitant rise in the expression of its downstream genes including VEGF, a protein with 
A

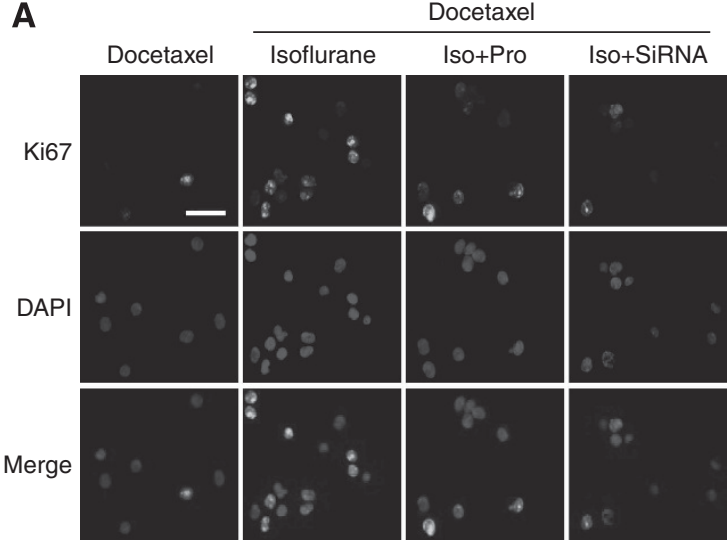

C

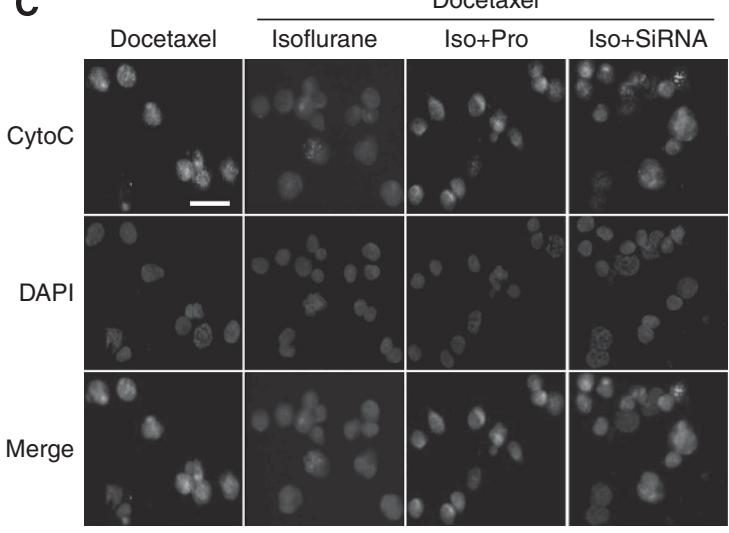

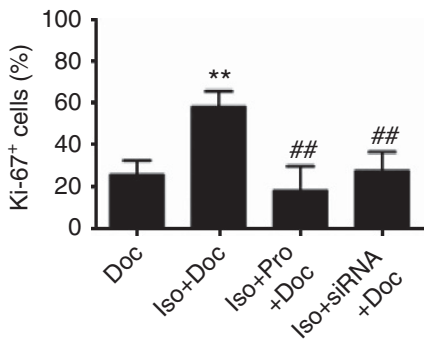

B

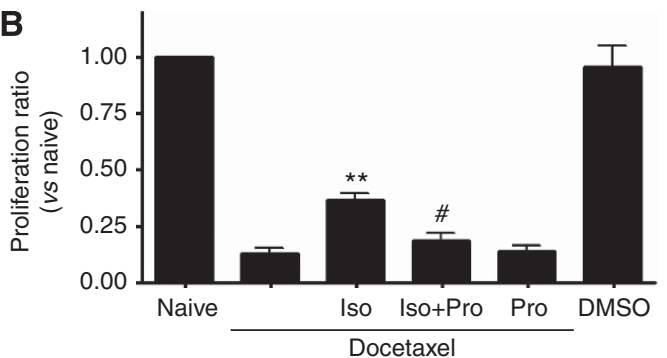

D

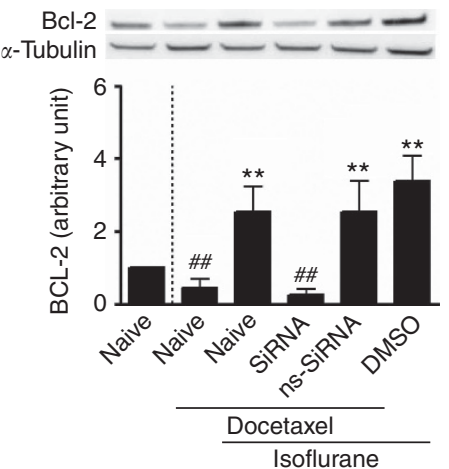

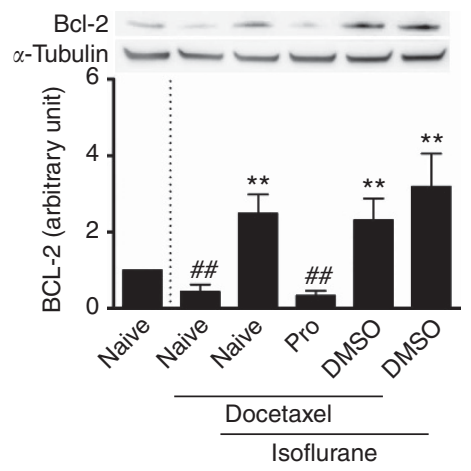

Figure 5. Propofol attenuated chemotherapy-resistance development induced by isoflurane exposure via inhibition of HIF-1 $\alpha$ in human prostate cancer cells. (A) Exposure to $2 \%$ isoflurane induced resistance against docetaxel (an anti-mitotic chemotherapy medication), shown as positive staining for Ki67, a marker for active mitosis (mean \pm s.d., $n=8 ;{ }^{* \star} P<0.001$ vs docetaxel; ${ }^{\# \#} P<0.001$ vs isoflurane + docetaxel); (B) MTT assay also demonstrated that with isoflurane pre-treatment, cells had a higher proliferation rate, which was prevented with propofol (mean \pm s.d., $n=6$; ${ }^{\star \star} P<0.01$ vs docetaxel; ${ }^{\#} P<0.05$ vs isoflurane + docetaxel); (C) cytochrome-c release, as a marker of cellular injury caused by decetaxel treatment, was reduced in isoflurane-exposed cells, while treatment with propofol at $4 \mu \mathrm{g} \mathrm{ml}^{-1}$ or HIF-1 $\alpha$-specific siRNA ( $20 \mathrm{nm)} \mathrm{restored} \mathrm{the} \mathrm{sensitivity} \mathrm{to}$ Dectaxel treatment; (D) anti-apopotic protein, Bcl-2 was also overexpressed following isoflurane exposure before chemotherapy challenge. All these changes in favour of cell survival were blocked by co-administration of propofol at $4 \mu \mathrm{g} \mathrm{ml}^{-1}$ or HIF- $1 \alpha$-specific siRNA (20 nM) with isoflurane ( $n=4 ;{ }^{* \star} P<0.001$ vs naïve control; ${ }^{\# \#} P<0.001$ vs isoflurane alone). Abbreviations: Doc $=$ docetaxel; Iso $=$ isoflurane; Pro $=$ propofol. Bar $=50 \mu \mathrm{m}$.

a critical role in establishing neovascularization to boost a tumour's supply of oxygen and nutrients, and Ki67, a nuclear protein required for cellular proliferation that is widely used as a clinical prognostic indicator. With the introduction of a HIF- $1 \alpha$-specific siRNA, the increased expression of these two proteins in response to isoflurane exposure was no longer seen. Considering the widespread use of volatile anaesthetics in clinical practice, it is rational to postulate that, during cancer surgery, cancer cells gain enhanced malignant transformation after exposure to isoflurane as a result of activation of HIF- $1 \alpha$. The current findings may tie up with the clinical observation that general anaesthesia was associated with increased risk of cancer recurrence in prostate cancer (Biki et al, 2008a).

One of the consequences of the rapid and uncontrolled proliferation that characterises cancer cells is that the developing tumour soon outstrips its blood supply, leading to hypoxia that is most severe at the tumour's inner core. Here, HIF-1 $\alpha$ levels are driven upward as the oxygen-dependent reactions that permit proteasomal degradation are limited. But HIF- $1 \alpha$ levels may also rise independently of oxygen via loss-of-function mutations to tumour suppressor genes, such as VHL and PTEN, or gain-offunction mutations to proto-oncogenes, or by activation of the
$\mathrm{PI} 3 \mathrm{~K} / \mathrm{Akt} / \mathrm{mTOR}$ and MAPK/ERK pathways involved in neosynthesis of HIF-1 $\alpha$ protein (Jiang et al, 2001). Various growth factors and cytokines including insulin, insulin-like growth factor, epidermal growth factor and interleukin-2 are known to activate these pathways and subsequently increase the rate of synthesis of HIF-1 $\alpha$ protein (Semenza, 2003a). To determine the contribution of $\mathrm{PI} 3 \mathrm{~K} / \mathrm{Akt} / \mathrm{mTOR}$ and MAPK/ERK pathways in isofluraneinduced upregulation of HIF- $1 \alpha$, we treated PC3 cells with the PI3K inhibitor LY294002 or the MAPK/ERK 1/2 inhibitor U0126 before exposure to isoflurane and found that the PI3K inhibitor abrogated the rise of HIF- $1 \alpha$, whereas the MEK $1 / 2$ inhibitor had little effect. High levels of phosphorylated Akt were also seen in response to isoflurane exposure, an effect abolished by pretreatment with LY294002. Our data obtained from prostate cancer cells and renal carcinoma cells (Benzonana et al, 2013) indicate that isoflurane upregulates the synthesis of HIF- $1 \alpha$ via the PI3K/ Akt/mTOR pathway. In addition, other previous studies have demonstrated that isoflurane could affect HIF- $1 \alpha$ expression in other cell lines, such as hepatocellular carcinoma Hep3B cells ( $\mathrm{Li}$ et al, 2006). All these studies provide strong evidence for the generality of isoflurane on HIF-1 expression in cancer cells. Hence, the multi-cellular effects including HIF- $1 \alpha$, Akt and their cascades 
A

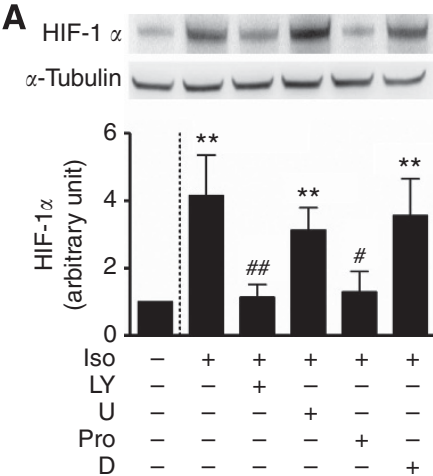

D

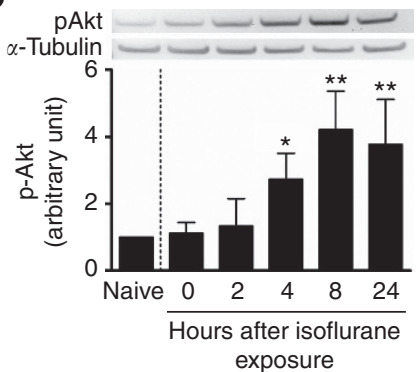

B

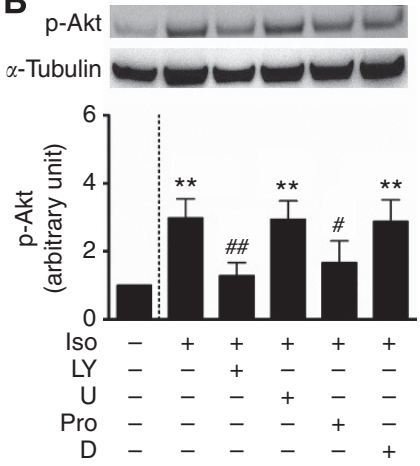

C

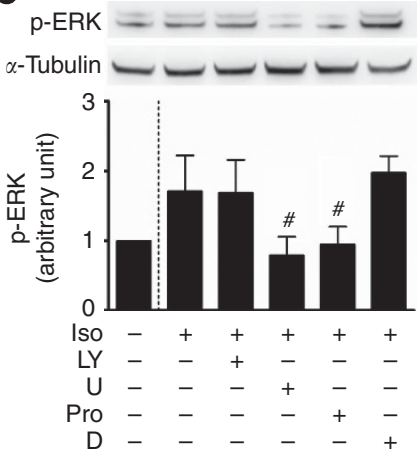

$\mathbf{E}$

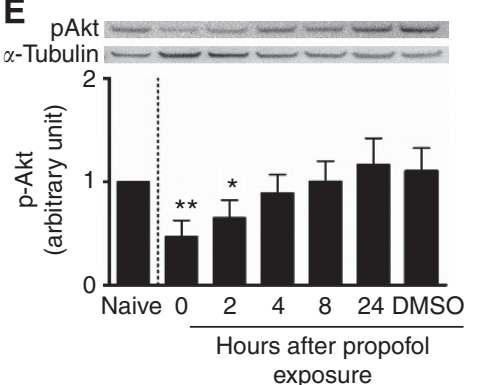

Figure 6. Molecular mechanisms of isoflurane (Iso)-induced hypoxia-inducible factor (HIF)-1 $\alpha$ expression in human prostate cancer cells. Cultured cells were treated with a PI-3K inhibitor, LY294002 (LY) (50 $\mu \mathrm{m})$, or an ERK inhibitor, U0126 (U) (50 $\mu \mathrm{m})$, dissolved in DMSO (D), for $16 \mathrm{~h}$ prior to $2 \%$ isoflurane, or $2 \%$ isoflurane combined with propofol (Pro) $\left(4 \mu \mathrm{g} \mathrm{ml}^{-1}\right)$ for $2 \mathrm{~h}$ and then cell extracts were used for western blotting $24 \mathrm{~h}$ after treatment. Other cohort cultured cells were exposed to $2 \%$ isoflurane or propofol (Pro) $\left(4 \mu \mathrm{g} \mathrm{ml}^{-1}\right)$ for $2 \mathrm{~h}$ and were then harvested immediately or 2-24h after exposure. (A) HIF-1 $\alpha$; (B) p-Akt; (C) p-ERK; (D, E) p-Akt vs time course. Results are mean \pm s.d. $(n=5)$; $P<0.05$; ${ }^{\star \star} P<0.01$ vs naïve control. ${ }^{\#} P<0.05$; ${ }^{\# \#} P<0.01$ vs Iso.

afforded by isoflurane ultimately promote cancer cell survival and growth toward anti-cancer treatment resistance.

HIFs have also been linked with chemoresistance. HIF- $1 \alpha$ regulates transcription of at least two genes, namely $A B C B 1$ and $A B C G 2$, belonging to the family of multi-specific drug efflux transporters that are responsible for the observed resistance to a widely used variety of cytotoxic agents such as taxanes, doxorubicin and Vinca alkaloids (Monti and Gariboldi, 2011). The HIF-regulated metabolic shift from oxidative to glycolytic mode and induction of carbonic anhydrase also hinders the delivery of these drugs to their intracellular targets (Greijer et al, 2005). We found that PC3 cells exposed to isoflurane showed significantly less response to the anti-mitotic chemotherapy agent, docetaxel, than naive controls, as evidenced by a higher proliferation rate, a higher proportion of cells seen to be in active mitosis, lower levels of the cell injury marker cytochrome $c$ and overexpression of the anti-apoptotic protein $\mathrm{Bcl}-2$. This resistance diminished when a HIF- $1 \alpha$-specific siRNA was introduced, supporting the expectation that this effect is mediated through isoflurane's upregulation of HIF- $1 \alpha$.

Propofol is widely used in clinical practice, largely due to its advantageous pharmacokinetic profile. It has been reported that propofol reduced the invasive capability of human cancer cells by inhibiting the formation of actin stress fibres and focal adhesion in HeLa human cervix carcinoma cells and inhibited pulmonary metastasis in a murine model of osteosarcoma (Mammoto et al, 2002), and enhanced the activity of cytotoxic $\mathrm{T}$ cells in mice (Kushida et al, 2007) and humans (Ren et al, 2010). In another distinguished trial, serum from patients receiving propofol/ paravertebral anaesthesia for breast cancer surgery inhibited proliferation of cultured breast cancer cell compared with serum from patients receiving sevoflurane/opioid anaesthesia-analgesia (Deegan et al, 2009). In addition, there are studies showing that propofol can negate the 'bad' or 'good' effects resulting from volatile anaesthetics exposure (Smul et al, 2010; Zhang et al, 2011) and that propofol suppresses HIF- $1 \alpha$ protein synthesis (Takabuchi et al, 2004b) as well as its downstream effects (Yeh et al, 2011).

Our data demonstrate that propofol inhibits upregulation of HIF- $1 \alpha$ by isoflurane as well as by copper chloride and hypoxia. Furthermore, it suppressed the rise of VEGF and Ki67 that had been observed after exposure to isoflurane and protected against isoflurane-induced resistance to docetaxel. These findings add further support to the growing evidence that propofol has properties against the malignant activities of cancer cells. Taken together with the experiments showing that propofol co-treatment reduces phosphorylation of Akt and suppresses upregulation of HIF- $1 \alpha$ by known inducers, it may be that propofol's inhibitory action on the PI3K pathway and HIF- $1 \alpha$ underpins its observed anti-tumour effects. However, while there are data indicating that the inhibition of HIF- $1 \alpha$ by propofol results from factors affecting its synthesis rather than its post-translational stabilisation (Takabuchi et al, 2004a; Tanaka et al, 2010), there is a relative paucity of detail on this subject which future work needs to elucidate. Interestingly, PC3 cells are known to have high p-Akt level due to loss of PTEN (Shukla et al, 2007). Our results show that isofluorane exposure induced even more p-Akt expression, which indicated that isofluorane could further enhance the tumour malignancy through increasing $\mathrm{p}$-AKT to even higher expression level but this warrants further study.

Clinical studies comparing the effect of general anaesthesia $v s$ the use of epidural anaesthesia on cancer recurrence have drawn different conclusions, and recent review articles have found the discrepancies too great to support a change in clinical practice at this time (Heaney and Buggy, 2012; Tavare et al, 2012). Our study demonstrates the importance of such studies not only 

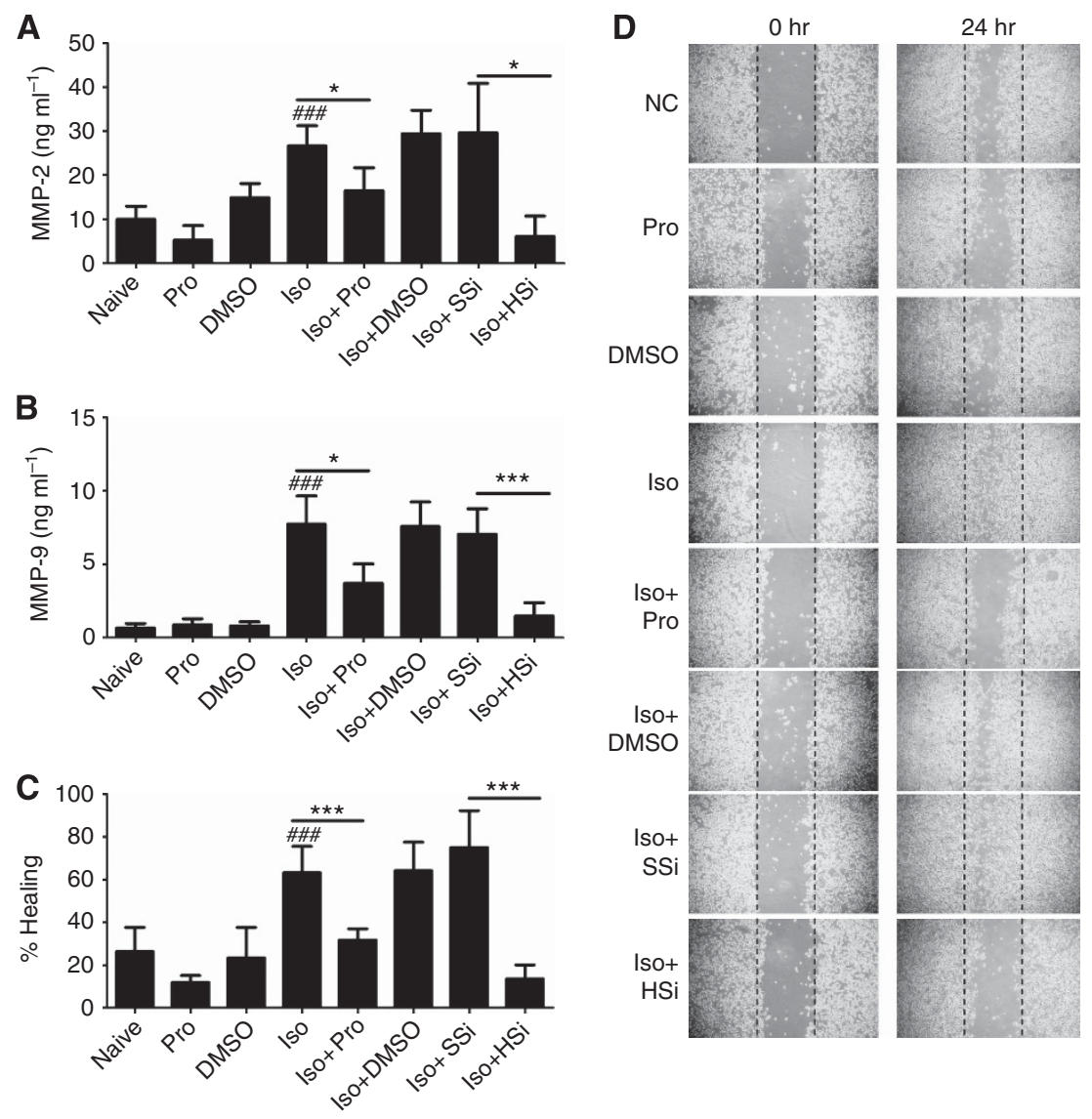

Figure 7. Isoflurane exposure enhanced human prostate cancer cell migration and invasion. (A and $\mathbf{B}$ ) ELISA assessment of MMP-2 and MMP-9 in the cell culture medium. (C and D) Scratch assay of PC3 cells before and $24 \mathrm{~h}$ after exposure to isoflurane demonstrated accelerated gap closure, while propofol at $4 \mu \mathrm{g} \mathrm{ml}^{-1}$ or HIF-1 $\alpha$-specific siRNA $(20 \mathrm{~nm})$ abolished these changes. Results are mean \pm s.d. $(n=4) ;{ }^{\star} P<0.01$ and ${ }^{\star * \star} P=0.001 ;{ }^{\#} P<0.001$, naive control vs isoflurane alone. Abbreviations: $\mathrm{HSi}=\mathrm{HIF}-1 \alpha$ siRNA; Iso = isoflurane; $\mathrm{NC}=$ naive control; Pro = propofol; $\mathrm{SSi}=$ scrambled siRNA.

differentiating between general and epidural anaesthesia but also among the type of general anaesthetic agents used.

Despite conducting our experiments using anaesthetics, doses and exposure periods that are clinically appropriate, in vitro studies are clearly limited in their ability to model tumour responses or the delivery of the anaesthetics to different tissues in vivo. For example, while we have shown propofol to suppress isoflurane's deleterious effects on cancer cell activity in vitro, we do not know whether the single dose given at induction in clinical practice is sufficient to protect against the far lengthier course of isoflurane administration or whether such protection could only be afforded by a sustained concentration of propofol over the course of the entire operation. Future work is needed to characterise the interaction between these two anaesthetics in a way that accurately reflects the timing and manner in which they are used clinically. This inevitably requires in vivo experiments or clinical trials to accurately account for the tumour's activities within its host and replicate the factors involved during surgery. In addition, in clinical settings, patients' conditions including anaesthetic regimens that are implemented during surgery are rather complex. Our augments would be much stronger if change of activation of signaling pathways is observed in xenograft tumours after being exposed to different anaesthetics, this certainly warrants further investigations in future studies. Simply, combined anaesthetics including opiods are essential for general anaesthesia. A previous elegant study showed that morphine-induced epidermal growth factor receptor phosphorylation leads to downstream MAPK/ERK and Akt phosphorylation and increased invasion in human lung cancer cultures (Fujioka et al, 2011). Morphine has also been reported in vitro and in vivo to promote cell proliferation and angiogenesis through cellular survival signals in human breast cancer cells (Gupta et al, 2002), whereas Fentanyl was found to activate HIF-1 $\alpha$ in neuroblastoma cells (Daijo et al, 2011). Furthermore, the genetic and phenotypic heterogeneity of cancer as a disease makes it highly likely that different cancer types will respond to anaesthetics in different ways, making it important to conduct such experiments using a variety of tumour types which are ongoing in the authors' laboratory.

The underlying molecular mechanism that isoflurane activates the PI3K/Akt pathway remains incompletely understood. It was demonstrated that isoflurane may activate the PI3K/Akt pathway by enhancing cytosolic calcium concentration via activation of inositol triphosphate receptors (Bickler and Fahlman, 2006; Bickler and Fahlman, 2010), with altered expression profile in genes regulating growth and survival. This observation is consistent with our studies. In addition, cytosolic calcium concentration has been demonstrated to be involved on cancer cell cycle progression and malignancy (Taylor et al, 2008). Furthermore, both isoflurane and propofol interact and activate GABA receptors (Garcia et al, 2010), but different from propofol, isoflurane inhibits NMDA receptor (Tsuda, 2010) and has been shown to significantly affect cytosolic calcium concentration (Xin et al, 2005). This may help to explain the notable difference between isoflurane and propofol on cancer cell growth and malignancy as observed in our studies. General anaesthetics have been increasingly shown to have dual effects of cytoprotection and cytotoxicity (Wei and Inan, 2013). Again, 
calcium has been shown to be involved: low dose for short duration is beneficial and promotes cell growth and proliferation, which induce endogenous cytoprotective mechanisms via moderate calcium release (Zuo, 2012; Wei and Inan, 2013). On the other hand, anaesthetics at high concentrations for prolonged duration is toxic to the cells and cause cell death via excessive and abnormal calcium release (Wei, 2011). Based on this, the association between general anaesthetics such as isoflurane and propofol, their duration and dose should be investigated in our future studies.

In conclusion, we have shown that isoflurane upregulates HIF$1 \alpha$ in prostate cancer cells via the PI3K/AKT/mTOR pathway, leading to concomitant increases in markers and mediators of angiogenesis, proliferation and chemoresistance. Meanwhile, the addition of propofol to isoflurane treatment suppresses all of those effects and appears to do so by antagonising phosphorylation of Akt. This study builds on the so far, primitive body of preclinical evidence that anaesthetics directly interfere with cancer cell biology and indicates that two of the most commonly used agents have disparate effects on HIF- $1 \alpha$ and its associated actions promoting malignant progression. Clinical studies examining the impact of anaesthetics on cancer recurrence should now account for this in their trial design or data interpretation and future work should begin to characterise the effects of common combinations of anaesthetics in a variety of tumour models that replicate the operative period as accurately as possible.

\section{ACKNOWLEDGEMENTS}

LLB was supported by MRC/DTA. HH was supported by a scholarship from Chinese Society of Anesthesiology, Beijing, China. DM's research has being supported with the grants from MRC, Alzheimer's Society-Bupa Foundation, BJA/RCoA, AAGBI, Westminster Medical School Research Trust, Action Medical Research and SPARKS, UK and European Society of Anesthesiology, Brussels.

\section{CONFLICT OF INTEREST}

The authors declare no conflict of interest.

\section{AUTHOR CONTRIBUTIONS}

$\mathrm{HH}$ and DM designed studies, while conception of the work was from DM. Cancer line was from CB. HH, LLB and HZ performed experiments and analysed data. HRW and NJSP participated experiments. All authors wrote manuscript.

\section{REFERENCES}

Ban HS, Uno M, Nakamura H (2010) Suppression of hypoxia-induced HIF-1alpha accumulation by VEGFR inhibitors: different profiles of AAL993 versus SU5416 and KRN633. Cancer Lett 296(1): 17-26.

Benzonana LL, Perry NJ, Watts HR, Yang B, Perry IA, Coombes C, Takata M, Ma D (2013) Isoflurane, a commonly used volatile anesthetic, enhances renal cancer growth and malignant potential via the hypoxia-inducible factor cellular signaling pathway in vitro. Anesthesiology 119: 593-605.

Bickler PE, Fahlman CS (2006) The inhaled anesthetic, isoflurane, enhances $\mathrm{Ca} 2+$-dependent survival signaling in cortical neurons and modulates MAP kinases, apoptosis proteins and transcription factors during hypoxia. Anesth Analg 103(2): 419-429.

Bickler PE, Fahlman CS (2010) Enhanced hypoxic preconditioning by isoflurane: signaling gene expression and requirement of intracellular $\mathrm{Ca} 2+$ and inositol triphosphate receptors. Brain Res 1340: 86-95.
Biki B, Mascha E, Moriarty D, Fitzpatrick J, Sessler D, Buggy D (2008a) Anesthetic technique for radical prostatectomy surgery affects cancer recurrence: a retrospective analysis. Anesthesiology 109(2): 180-187.

Biki B, Mascha E, Moriarty DC, Fitzpatrick JM, Sessler DI, Buggy DJ (2008b) Anesthetic technique for radical prostatectomy surgery affects cancer recurrence: a retrospective analysis. Anesthesiology 109(2): 180-187.

Bray F, Jemal A, Grey N, Ferlay J, Forman D (2012) Global cancer transitions according to the Human Development Index (2008-2030): a populationbased study. Lancet Oncol 13(8): 790-801.

Burrows N, Babur M, Resch J, Ridsdale S, Mejin M, Rowling EJ, Brabant G, Williams KJ (2011) GDC-0941 inhibits metastatic characteristics of thyroid carcinomas by targeting both the phosphoinositide- 3 kinase (PI3K) and hypoxia-inducible factor-1alpha (HIF-1alpha) pathways. J Clin Endocrinol Metab 96(12): E1934-E1943.

Christopherson R, James KE, Tableman M, Marshall P, Johnson FE (2008) Long-term survival after colon cancer surgery: a variation associated with choice of anesthesia. Anesth Analg 107(1): 325-332.

Daijo H, Kai S, Tanaka T, Wakamatsu T, Kishimoto S, Suzuki K, Harada H, Takabuchi S, Adachi T, Fukuda K, Hirota K (2011) Fentanyl activates hypoxia-inducible factor 1 in neuronal SH-SY5Y cells and mice under non-hypoxic conditions in a mu-opioid receptor-dependent manner. Eur J Pharmacol 667(1-3): 144-152.

de Oliveira Jr GS, Ahmad S, Schink JC, Singh DK, Fitzgerald PC, McCarthy RJ (2011) Intraoperative neuraxial anesthesia but not postoperative neuraxial analgesia is associated with increased relapse-free survival in ovarian cancer patients after primary cytoreductive surgery. Reg Anesth Pain Med 36(3): 271-277.

Deegan CA, Murray D, Doran P, Ecimovic P, Moriarty DC, Buggy DJ (2009) Effect of anaesthetic technique on oestrogen receptor-negative breast cancer cell function in vitro. Br J Anaesth 103(5): 685-690.

Eisinger-Mathason TS, Simon MC (2010) HIF-1alpha partners with FoxA2, a neuroendocrine-specific transcription factor, to promote tumorigenesis. Cancer Cell 18(1): 3-4.

Exadaktylos AK, Buggy DJ, Moriarty DC, Mascha E, Sessler DI (2006) Can anesthetic technique for primary breast cancer surgery affect recurrence or metastasis? Anesthesiology 105(4): 660-664.

Fujioka N, Nguyen J, Chen C, Li Y, Pasrija T, Niehans G, Johnson KN, Gupta V, Kratzke RA, Gupta K (2011) Morphine-induced epidermal growth factor pathway activation in non-small cell lung cancer. Anesth Analg 113(6): 1353-1364.

Garcia PS, Kolesky SE, Jenkins A (2010) General anesthetic actions on GABA(A) receptors. Curr Neuropharmacol 8(1): 2-9.

Gopinathan L, Tan SL, Padmakumar VC, Coppola V, Tessarollo L, Kaldis P (2014) Loss of Cdk2 and cyclin A2 impairs cell proliferation and tumorigenesis. Cancer Res 74(14): 3870-3879.

Gottschalk A, Brodner G, Van Aken HK, Ellger B, Althaus S, Schulze HJ (2012) Can regional anaesthesia for lymph-node dissection improve the prognosis in malignant melanoma? Br J Anaesth 109(2): 253-259.

Gottschalk A, Ford JG, Regelin CC, You J, Mascha EJ, Sessler DI, Durieux ME, Nemergut EC (2010) Association between epidural analgesia and cancer recurrence after colorectal cancer surgery. Anesthesiology 113(1): 27-34.

Greijer AE, de Jong MC, Scheffer GL, Shvarts A, van Diest PJ, van der Wall E (2005) Hypoxia-induced acidification causes mitoxantrone resistance not mediated by drug transporters in human breast cancer cells. Cell Oncol 27(1): 43-49.

Gupta K, Kshirsagar S, Chang L, Schwartz R, Law PY, Yee D, Hebbel RP (2002) Morphine stimulates angiogenesis by activating proangiogenic and survival-promoting signaling and promotes breast tumor growth. Cancer Res 62(15): 4491-4498.

Heaney A, Buggy DJ (2012) Can anaesthetic and analgesic techniques affect cancer recurrence or metastasis? Br J Anaesth 109(Suppl 1): i17-i28.

$\mathrm{Hu}$ J, Verkman AS (2006) Increased migration and metastatic potential of tumor cells expressing aquaporin water channels. FASEB J 20(11): 1892-1894.

Jiang BH, Jiang G, Zheng JZ, Lu Z, Hunter T, Vogt PK (2001) Phosphatidylinositol 3-kinase signaling controls levels of hypoxiainducible factor 1. Cell Growth Differ 12(7): 363-369.

Kushida A, Inada T, Shingu K (2007) Enhancement of antitumor immunity after propofol treatment in mice. Immunopharmacol Immunotoxicol 29(3-4): 477-486.

Li QF, Wang XR, Yang YW, Su DS (2006) Up-regulation of hypoxia inducible factor lalpha by isoflurane in Hep3B cells. Anesthesiology 105(6): 1211-1219. 
Liang CC, Park AY, Guan JL (2007) In vitro scratch assay: a convenient and inexpensive method for analysis of cell migration in vitro. Nat Protoc 2(2): 329-333.

Liao D, Johnson RS (2007) Hypoxia: a key regulator of angiogenesis in cancer. Cancer Metastasis Rev 26(2): 281-290.

Lin L, Liu C, Tan H, Ouyang H, Zhang Y, Zeng W (2011) Anaesthetic technique may affect prognosis for ovarian serous adenocarcinoma: a retrospective analysis. Br J Anaesth 106(6): 814-822.

Ma D, Lim T, Xu J, Tang H, Wan Y, Zhao H, Hossain M, Maxwell PH, Maze M (2009) Xenon preconditioning protects against renal ischemicreperfusion injury via HIF-1alpha activation. J Am Soc Nephrol 20(4): 713-720.

Mammoto T, Mukai M, Mammoto A, Yamanaka Y, Hayashi Y, Mashimo T, Kishi Y, Nakamura H (2002) Intravenous anesthetic, propofol inhibits invasion of cancer cells. Cancer Lett 184(2): 165-170.

Monti E, Gariboldi MB (2011) HIF-1 as a target for cancer chemotherapy, chemosensitization and chemoprevention. Curr Mol Pharmacol 4(1): $62-77$.

Ren XF, Li WZ, Meng FY, Lin CF (2010) Differential effects of propofol and isoflurane on the activation of T-helper cells in lung cancer patients. Anaesthesia 65(5): 478-482.

Semenza GL (2003a) Targeting HIF-1 for cancer therapy. Nat Rev Cancer 3(10): 721-732.

Semenza G (2010) Defining the role of hypoxia-inducible factor 1 in cancer biology and therapeutics. Oncogene 29(5): 625-634.

Semenza GL (2003b) Targeting HIF-1 for cancer therapy. Nat Rev Cancer 3(10): 721-732.

Semenza GL (2012) Hypoxia-inducible factors: mediators of cancer progression and targets for cancer therapy. Trends Pharmacol Sci 33(4): 207-214.

Shukla S, Maclennan GT, Hartman DJ, Fu P, Resnick MI, Gupta S (2007) Activation of PI3K-Akt signaling pathway promotes prostate cancer cell invasion. Int J Cancer 121(7): 1424-1432.

Smul TM, Stumpner J, Blomeyer C, Lotz C, Redel A, Lange M, Roewer N, Kehl F (2010) Propofol inhibits desflurane-induced preconditioning in rabbits. J Cardiothorac Vasc Anesth 25(2): 276-281.

Takabuchi S, Hirota K, Nishi K, Oda S, Oda T, Shingu K, Takabayashi A, Adachi T, Semenza G, Fukuda K (2004a) The intravenous anesthetic propofol inhibits hypoxia-inducible factor 1 activity in an oxygen tension-dependent manner. FEBS Lett 577(3): 434-438.

Takabuchi S, Hirota K, Nishi K, Oda S, Oda T, Shingu K, Takabayashi A, Adachi T, Semenza GL, Fukuda K (2004b) The intravenous anesthetic propofol inhibits hypoxia-inducible factor 1 activity in an oxygen tension-dependent manner. FEBS Lett 577(3): 434-438.

Talks K, Turley H, Gatter K, Maxwell P, Pugh C, Ratcliffe P, Harris A (2000) The expression and distribution of the hypoxia-inducible factors
HIF-1alpha and HIF-2alpha in normal human tissues, cancers, and tumor-associated macrophages. Am J Pathol 157(2): 411-421.

Tanaka T, Takabuchi S, Nishi K, Oda S, Wakamatsu T, Daijo H, Fukuda K, Hirota K (2010) The intravenous anesthetic propofol inhibits lipopolysaccharide-induced hypoxia-inducible factor 1 activation and suppresses the glucose metabolism in macrophages. J Anesth 24(1): 54-60.

Tavare AN, Perry NJ, Benzonana LL, Takata M, Ma D (2012) Cancer recurrence after surgery: direct and indirect effects of anesthetic agents. Int J Cancer 130(6): 1237-1250.

Taylor JT, Zeng XB, Pottle JE, Lee K, Wang AR, Yi SG, Scruggs JA, Sikka SS, Li M (2008) Calcium signaling and T-type calcium channels in cancer cell cycling. World J Gastroenterol 14(32): 4984-4991.

Terraneo L, Bianciardi P, Caretti A, Ronchi R, Samaja M (2010) Chronic systemic hypoxia promotes LNCaP prostate cancer growth in vivo. Prostate 70(11): 1243-1254.

Tsuda K (2010) Neuroprotective effect of isoflurane and N-methyl-D-aspartate receptors in ischemic brain injury. Stroke 41(10): e578.

Wang H, Bian S, Yang CS (2011) Green tea polyphenol EGCG suppresses lung cancer cell growth through upregulating miR-210 expression caused by stabilizing HIF-1alpha. Carcinogenesis 32(12): 1881-1889.

Wei H (2011) The role of calcium dysregulation in anesthetic-mediated neurotoxicity. Anesth Analg 113(5): 972-974.

Wei H, Inan S (2013) Dual effects of neuroprotection and neurotoxicity by general anesthetics: role of intracellular calcium homeostasis. Prog Neuropsychopharmacol Biol Psychiatry 47: 156-161.

Welden B, Gates G, Mallari R, Garrett N (2009) Effects of anesthetics and analgesics on natural killer cell activity. AANA J 77(4): 287-292.

Xin WK, Kwan CL, Zhao XH, Xu J, Ellen RP, McCulloch CA, Yu XM (2005) A functional interaction of sodium and calcium in the regulation of NMDA receptor activity by remote NMDA receptors. J Neurosci 25(1): 139-148.

Yeh CH, Cho W, So EC, Chu CC, Lin MC, Wang JJ, Hsing CH (2011) Propofol inhibits lipopolysaccharide-induced lung epithelial cell injury by reducing hypoxia-inducible factor-1alpha expression. Br J Anaesth 106(4): 590-599.

Zhang Y, Zhen Y, Dong Y, Xu Z, Yue Y, Golde TE, Tanzi RE, Moir RD, Xie Z (2011) Anesthetic propofol attenuates the isoflurane-induced caspase-3 activation and Abeta oligomerization. PLoS One 6(11): e27019.

Zuo Z (2012) Are volatile anesthetics neuroprotective or neurotoxic? Med Gas Res 2(1): 10.

This work is published under the standard license to publish agreement. After 12 months the work will become freely available and the license terms will switch to a Creative Commons AttributionNonCommercial-Share Alike 3.0 Unported License.

Supplementary Information accompanies this paper on British Journal of Cancer website (http://www.nature.com/bjc) 